\title{
Characterization of the useful life and structural performance of a reinforced concrete bridge in the City of Correntes-PE
}

Caracterização da vida útil e desempenho estrutural de uma ponte de concreto armado na Cidade de Correntes-PE

Caracterización de la vida útil y comportamiento estructural de un puente de hormigón armado en la Ciudad de Correntes-PE

Renan Gustavo Pacheco Soares

ORCID: https://orcid.org/0000-0002-6366-9663

Universidade Federal de Pernambuco, Brazil E-mail: renangpsoares@ hotmail.com

Gustavo Gutierrez de Oliveira Rodrigues

ORCID: https://orcid.org/0000-0001-8617-0120

Universidade Regional de Blumenau, Brazil

E-mail: gustavogutierrez01@hotmail.com

Iago Davi Lins De Moraes

ORCID: https://orcid.org/0000-0002-3877-076X

Autarquia do Ensino Superior de Garanhuns, Brazil

E-mail: iagodavi96@hotmail.com

Carla Renata Xavier Pacheco

ORCID: https://orcid.org/0000-0003-0064-9339 Autarquia do Ensino Superior de Garanhuns, Brazil

E-mail: carla_renatax@hotmail.com

Lyneker Souza de Moura

ORCID: https://orcid.org/0000-0002-9343-6916

Universidade Federal de Pernambuco, Brazil E-mail: lyneker@gmail.com

Kaike Manoel Barros do Nascimento

ORCID: https://orcid.org/0000-0002-8127-3005

Autarquia do Ensino Superior de Garanhuns, Brazil E-mail: kaike41@hotmail.com

Priscila Honório Apolônio

ORCID: https://orcid.org/0000-0003-4820-868X

Universidade Federal de Pernambuco, Brazil

E-mail: priscilahonorio@ aesga.edu.br

Arnaldo Manoel Pereira Carneiro

ORCID: https://orcid.org/0000-0002-4279-7156

Universidade Federal de Pernambuco, Brazil

E-mail: arnaldo.carneiro@ufpe.br

Romilde Almeida de Oliveira

ORCID: https://orcid.org/0000-0002-6786-9080

Universidade Federal de Pernambuco, Brazil

E-mail: romildealmeida@gmail.com

\begin{abstract}
Even though we know that the construction industry is constantly evolving, due to the emergence of construction techniques and materials, we note that there are still challenges to be faced: pathological manifestations. These, in turn, compromise the performance and useful life of the elements. Its occurrences are mainly due to the reduction of deadlines, inadequate design solutions, improper use of materials, unskilled labor, lack of maintenance, lack of inspection, among other aspects. The evaluation of a structural element is based on the precedence of guaranteeing durability and quality to ensure the integrity of users. Therefore, this article analyzed structural elements of a reinforced concrete bridge located in the city of Correntes-PE. The main objective of the work was to characterize the main pathological manifestations affecting the structural elements of the bridge. The process of characterization of degrading agents was carried out through non-destructive tests, such as the carbonation front, as provided for in EN 14630 (DIN, 2007) and the evaluation of surface resistance, through the sclerometry test, according to NBR 7584 (ABNT, 2012). The results allowed to characterize the strength of the concrete and the degree of degradation. Points
\end{abstract}


with incidence of carbonation and exposed reinforcement were identified, denoting the need for preventive and corrective intervention, in order to prolong the useful life and performance of the evaluated artwork.

Keywords: Pathological manifestarions; Reinforced concrete; Lifespan; Performance; Bridges.

\section{Resumo}

Mesmo sabendo que a indústria da construção civil está em constante evolução, mediante o surgimento de técnicas e materiais de construção, nota-se que ainda há desafios a serem encarados: as manifestações patológicas. Estas, por sua vez, comprometem o desempenho e vida útil dos elementos. As suas ocorrências se dão principalmente pela redução de prazos, soluções inadequadas de projeto, uso indevido de materiais, mão de obra desqualificada, falta de manutenção, ausência de fiscalização, dentre outros aspectos. A avaliação de um elemento estrutural fundamenta-se na precedência da garantia da durabilidade e qualidade para assegurar a integridade dos usuários. Diante disso, o presente artigo analisou elementos estruturais de uma ponte de concreto armado situada na cidade de Correntes-PE. O objetivo principal do trabalho foi caracterizar as principais manifestações patológicas incidentes nos elementos estruturais da ponte. O processo de caracterização dos agentes degradantes foi feito através de ensaios não destrutivos, como o de frente de carbonatação, conforme prevê a EN 14630 (DIN, 2007) e a avaliação de resistência superficial, através do ensaio de esclerometria, conforme NBR 7584 (ABNT, 2012). Os resultados permitiram caracterizar a resistência do concreto e o grau de degradação. Pontos com incidência de carbonatação e armaduras expostas foram identificados, denotando necessidade de intervenção de cunho preventivo e corretivo, de modo a prolongar a vida útil e desempenho da obra de arte avaliada.

Palavras-chave: Manifestações patológicas; Concreto armado; Vida útil; Desempenho; Pontes.

\section{Resumen}

Si bien sabemos que la industria de la construcción está en constante evolución, debido al surgimiento de técnicas y materiales de construcción, notamos que aún quedan desafíos por enfrentar: las manifestaciones patológicas. Estos, a su vez, comprometen el rendimiento y la vida útil de los elementos. Sus ocurrencias se deben principalmente a la reducción de plazos, soluciones de diseño inadecuadas, uso inadecuado de materiales, mano de obra no calificada, falta de mantenimiento, falta de inspección, entre otros aspectos. La evaluación de un elemento estructural se basa en la prioridad de garantizar la durabilidad y la calidad para asegurar la integridad de los usuarios. Por tanto, este artículo analiza los elementos estructurales de un puente de hormigón armado ubicado en la ciudad de Correntes-PE. El objetivo principal del trabajo fue caracterizar las principales manifestaciones patológicas que afectan los elementos estructurales de la puente. El proceso de caracterización de los agentes degradantes se realizó mediante ensayos no destructivos, como el frente de carbonatación, según lo previsto en la EN 14630 (DIN, 2007) y la evaluación de la resistencia superficial, mediante el ensayo de esclerometría, según NBR 7584 (ABNT, 2012). Los resultados permitieron caracterizar la resistencia del hormigón y el grado de degradación. Se identificaron puntos con incidencia de carbonatación y refuerzo expuesto, denotando la necesidad de una intervención preventiva y correctiva, con el fin de prolongar la vida útil y desempeño de la obra de arte evaluada.

Palabras clave: Manifestaciones patológicas; Concreto armado; Vida útil; Rendimiento; Puentes.

\section{Introduction}

Even knowing that the construction industry operates in a constant evolutionary line with regard to the development of new construction techniques, one of the factors that is still identified as a challenge to be faced is in relation to pathological manifestations. These can compromise the performance and reduce the useful life of the elements exposed to such effects (Scrivener, 2014; John \& Gleize, 2017).

An alternative for the identification and insertion of preventive and corrective actions in the structural systems, specifically in bridges, is to carry out periodic inspections. Inspections allow professionals to identify the current state of conservation of structural systems. Also, propose actions for prevention and / or repair, when necessary. All of this with a focus on service performance and user safety.

When a pathological process is identified in an element, the appearance of pathological manifestations is not initially attributed to just one factor, since there are a variety of probable causes for its occurrence. Attack through chemical agents, automobile accidents, bad weather and overloads that were not foreseen in the planning stage are some situations that can occur. 
In view of this, the understanding about the occurrence and probable causes of pathological manifestations, becomes an object of great relevance, considering that the performance of such counterparts directly in the reinforced concrete structures elements can jeopardize the entire security of the system.

Reinforced concrete bridges are systems that constantly suffer from the incidence of pathological problems. This is due to several factors, such as its location above streams, river crossing, urban overflow areas, regions with untreated effluents, in addition, of course, the effects caused by gas emissions due to the cars that circulate through them. Nevertheless, the lack of periodic inspection and preventive maintenance tends to accelerate the system's degenerative process.

In addition, the negative influences caused by the contact of harmful agents with the structures can affect the overall stability of the work. The reduction of stiffness and the loss of cross-section of exposed reinforcement, for example, causes the system components to be affected as well. And this directly interferes with service performance and ultimate capacity (Candian, 2017).

Not only the effects resulting from the impacts of pathological manifestations must be taken into account, but also the culture of the lack of periodic maintenance on the bridges that Brazil has in all its construction context. Such lack of maintenance accelerates the effects of degradation of bridges and viaducts, thus having a greater need for promoting procedures in order to re-establish the minimum safety conditions of the compromised elements (Wajdowicz, 2017).

One of the great insights from the scientific community is about the need to identify the agents and the causes of such adverse effects on structures. For the case in question, the bridges. The idea is to implement efficient maintenance methods in order to provide greater longevity to the bridges (Euqueres, 2011).

In view of this, this work aimed to characterize the possible pathological manifestations present in the structural elements of a concrete bridge located in the city of Correntes-PE. Non-destructive tests of carbonation and sclerometry were performed. For the carbonation test, a phenolphthalein solution was used, with a focus on identifying the carbonated regions or not. For the sclerometry test, the surface hardness test was performed for correlation with the characteristic resistance in loco. Finally, a visual analysis was carried out to verify any appearance of reinforcement with problems of corrosion and incidence of efflorescence.

\section{Inspection and Diagnosis of Pathological Manifestations in Reinforced Concrete Structures}

Among the materials most used in the structural systems of this modern era, reinforced concrete stands out. Its use on a large scale goes back mainly to concepts of durability, mechanical performance, good cost-benefit compared to other construction systems and also the availability of inputs for its manufacture.

Reinforced concrete was initially applied in Europe, around the 19th century. Until then, conventional concrete was one of the few materials used as a component of a structure. To this end, the French identified that when steel was inserted together with concrete, this system had its value of increased rigidity and resistance to mechanical efforts, thus being able to modulate several architectural formats (Mehta \& Monteiro, 1994; Soares, 2017; Sadati et al., 2016).

The use of this type of structural system has been widely used by designers. In Brazil, one of the precursors in the understanding and application of concrete was the engineer Emílio Baumgart, from Blumenau-SC, Brazil. Over the years, the structural system of reinforced concrete has become the most used in the country, where practically all the surroundings you look at, it is possible to identify elements in reinforced concrete (Pamponet \& Sánchez, 2016).

In view of all the diffusion of reinforced concrete structures, it was realized that it was necessary to understand the effects that could be caused over the years, as well as the implications that this system could suffer when subjected to adverse situations. Concomitantly to these points, the concepts regarding pathological manifestations became more evident and 
debated, considering that the structures tended to present problems regarding the expected performance. For Helene (1992), the study of pathological manifestations can be understood as an area of civil engineering whose core is to study the symptoms, mechanisms, causes and origins of problems in civil construction; the study of the parts that will verify the final diagnosis. This study is important not only for them to be characterized and remedied, but also to be avoided, contributing to quality control and the consequent reduction in building repair costs.

The analysis of pathological manifestations is also a function of two fundamental aspects: conditions of exposure and time (Andrade \& Silva, 2005). Under conditions of exposure, importance must be given to the Class of Environmental Aggressiveness to which the structure is subjected. The knowledge of the degree of deterioration, possible chemical attacks, contacts with contaminated areas, maritime regions, among others, can accelerate the incidence of problems and reduce durability. Thus, the entire construction context must be considered, from the design criteria, its execution, proper use and periodic maintenance.

Analyzing the time aspect, it is known that every structural system over the years tends to suffer natural wear and tear, both due to use and by agents that can reduce its durability.

In this respect, the performance of the structure is directly linked, because if the conditions of exposure and the time act in a conditioning way to reduce its performance, soon the structure can have its useful life reduced. Thus, with the appearance of pathological problems, the costs of intervention to make the structure able to continue to carry out the planned activities, try to be increasingly high.

The growth of these costs can be compared to that of a geometric progression of ratio 5, known as the "Law of 5" or Sitter's rule (Sitter, 1984 apud Helene, 1997) (Figure 1).

Figure 1. Cost of maintaining the structure as a function of time.

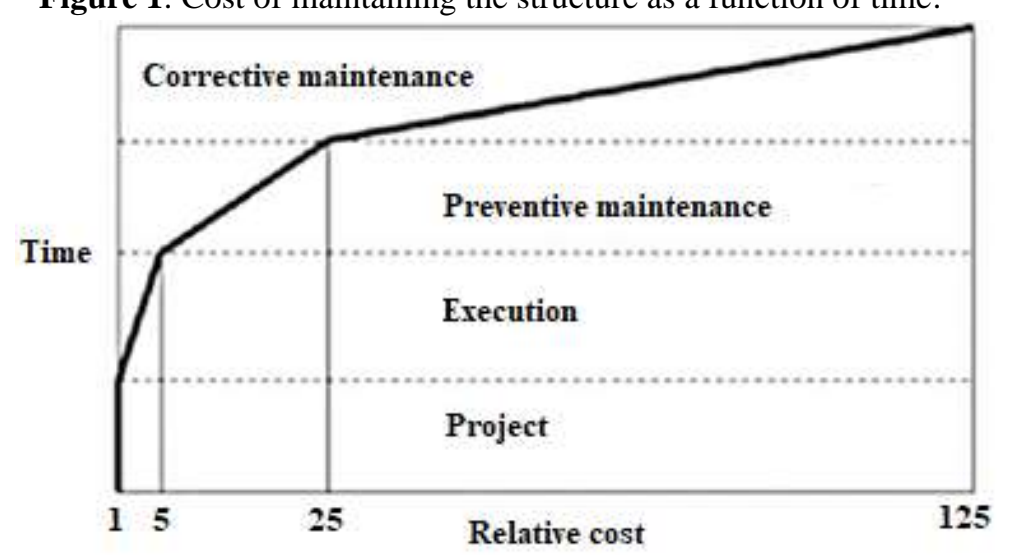

Source: Adapted from Sitter (1984 apud Helene, 1997).

As shown in Figure 1, when the changes are made in the design phase, this cost is right 1, as it is still in the planning phase. When the adjustments are made in the stages of execution, preventive and corrective maintenance, these values correspond to 5, 25 and 125 , respectively.

Therefore, in terms of maintenance promotion, it is evident the need for changes to be preferably made in the design phase, as the structure is still in the planning process and the costs of changes will be considerably lower when analyzed and carried out in the other stages. Thus, sooner the pathology is diagnosed and treated, the lower the cost and the more advanced the work or the damage evolves, the greater the cost for recovery, growing exponentially.

There are several causes for the appearance of pathological manifestations. They can be linked to several phases, such as project design, quality of materials, errors in execution, incorrect use, absence of maintenance, among other factors. In 
Figure 2, a survey carried out in several works with incidence of pathological manifestations can be identified. In this case, studies were carried out on the possible causes of the problem's occurrences.

Figure 2. Causes of pathologies;

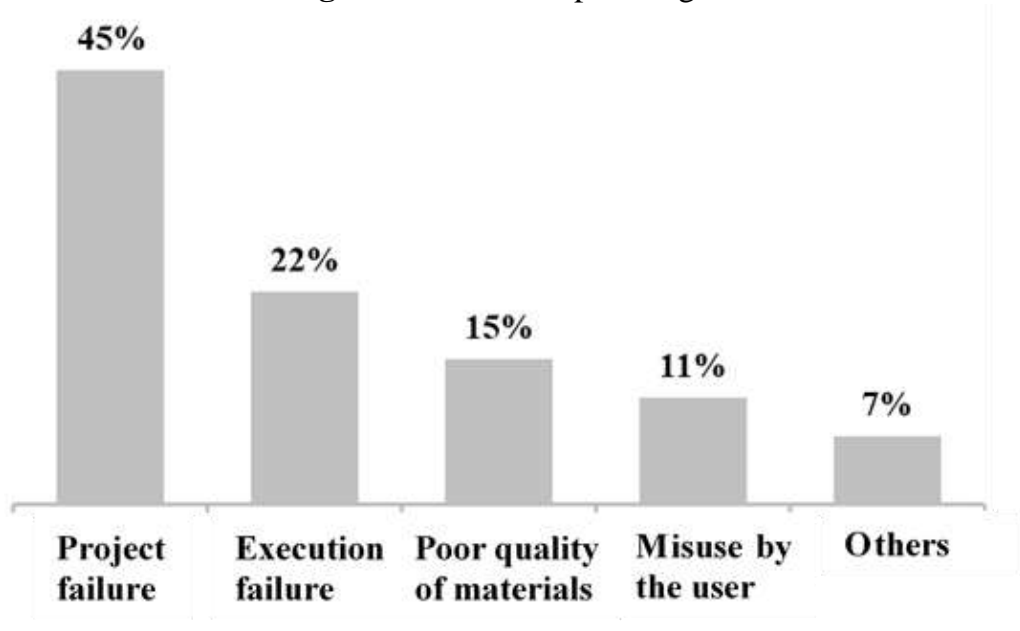

Source: Adapted from Couto e Couto (2007)

As can be seen (Figure 2), almost half of the problems identified were linked to project failures, followed by execution failures and other factors. There is a core of thinking about obtaining this data, especially when it comes to design and execution failures.

Analyzing the execution failures in isolation, in addition to the difficulties and errors in the project that may exist, the lack of qualified labor and professionals who strictly follow what was foreseen in the project, causes harmful damages to the structure, thus reducing the system performance and durability.

Pathological manifestations must always be diagnosed and treated correctly. It is not just a type of medicine that treats all types of illness. Each case is different. It should be noted that, at times, a diagnosis carried out imprecisely, without theoretical foundation or even technical competence has caused inconvenience and only further aggravated the situation. Therefore, experts with experience for inspection and diagnosis of structural systems should always be valued.

Among the various problems that can occur in reinforced concrete bridges, some end up being found more frequently, such as carbonation. It is "a physical-chemical phenomenon arising from the reactions of acidic gases in the environment with alkaline concrete products. The alkalinity of the concrete is mainly conferred by the presence of calcium hydroxide $(\mathrm{Ca}(\mathrm{OH})$ 2), sodium $(\mathrm{NaOH})$ and potassium $(\mathrm{KOH})$, dissolved or precipitated in the hardened concrete. " (Possan, 2004).

For Neumann Junior (2019), another problem that occurs in reinforced concrete structures is the effect of efflorescence. Fruit of the passage of water in the pores of the concrete, with the dissolution and transport of calcium hydroxide, which is leaching. This compound is deposited on the concrete surface, forming white spots.

It should be noted that there are several other pathologies that can put safety at risk. Therefore, it is necessary that periodic inspections are carried out in order to identify the beginning of the activation of such activities, and that they are treated correctly and precisely, so that the structure can have its time of use prolonged in a safe, according with NBR 16747 (ABNT, 2020). 


\section{Methodology}

Considering the need to carry out inspections in order to identify the possible pathological manifestations active in the structure, it is evident the need to carry out tests with a non-destructive or destructive character, aiming to identify the degree of impact that effect causes in the structure.

With the delay or even the absence of inspections, the structures end up suffering too many impacts, especially when their use time is long. Therefore, this study carried out a brief inspection on a reinforced concrete bridge located in CorrentesPE, in order to identify possible pathological manifestations. In Figure 3, the studied bridge can be identified.

Figure 3. Bridge in the city of Correntes-PE.

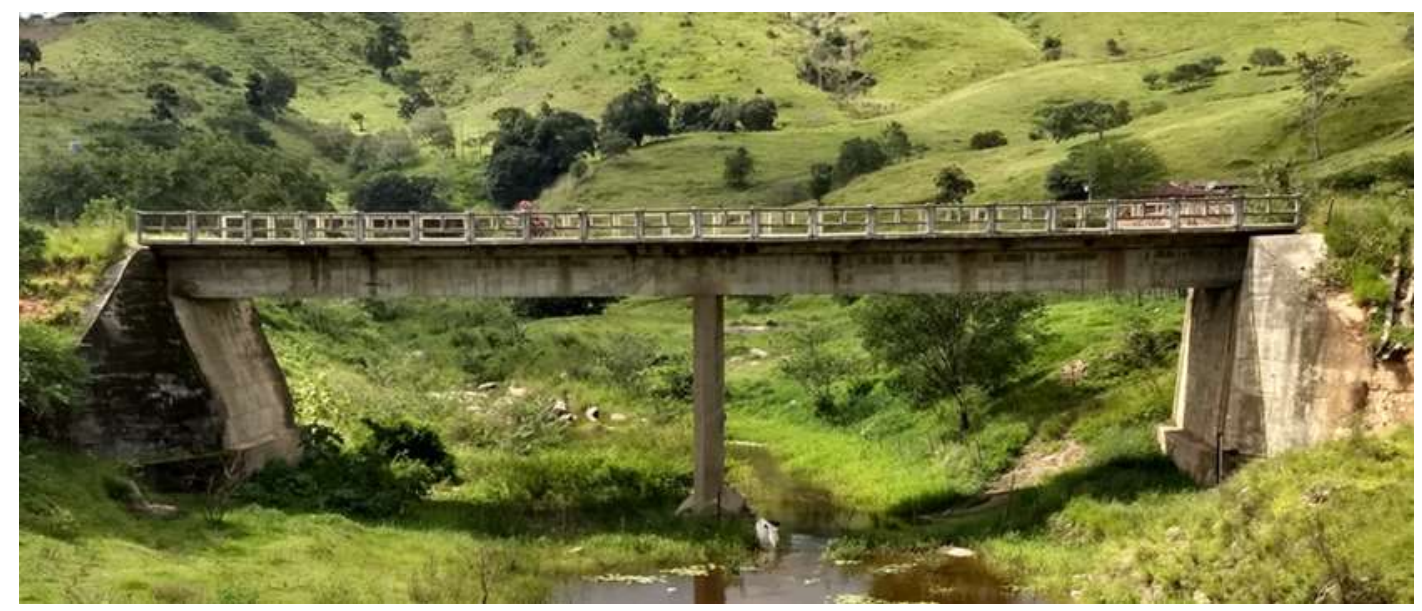

Source: Authors (2021).

The bridge shown in Figure 3 is approximately $40 \mathrm{~m}$ long and $9 \mathrm{~m}$ wide, with a height of approximately $12 \mathrm{~m}$. It was not possible to access the project's structure. Sclerometry tests were performed to determine the surface hardness of the concrete, in order to estimate the characteristic strength. This test was carried out according to the guidelines established by NBR 7584 (ABNT, 2012), with the use of a reflection sclerometer.

As foreseen in the norm, areas were selected in which the surface hardness presented the result closest to reality, and the 16 points were marked for conducting the collection of resistances after readings. For the execution, the area to be tested was previously prepared with polishing, in order to provide a better surface of the structure.

After the sclerometry test, a carbonation test was performed on the surface of the bridge, as there was no release to perform it in a deeper area of the structure. The test consisted of spraying the phenolphthalein solution in a previously cleaned area. Therefore, a visual inspection was carried out to identify reinforcement with corrosion and efflorescence problems. Finally, the possible causes of the pathological manifestations found were analyzed.

To obtain the results regarding the sclerometry test, a reflection sclerometer was used, being applied perpendicularly, so that the collected results demonstrate the best physical condition, to obtain the results regarding the surface hardness. The tests were carried out on the two footbridges of the bridge and also on a central column.

\section{Results and Discussion}

In Figure 4, the indicated locations represent the positions of the sclerometry tests. These tests were carried out on the central pillar of the bridge. 
Research, Society and Development, v. 10, n. 5, e4810514579, 2021

(CC BY 4.0) | ISSN 2525-3409 | DOI: http://dx.doi.org/10.33448/rsd-v10i5.14579

Figure 4. Conducting sclerometry tests on the catwalks and central pillar.

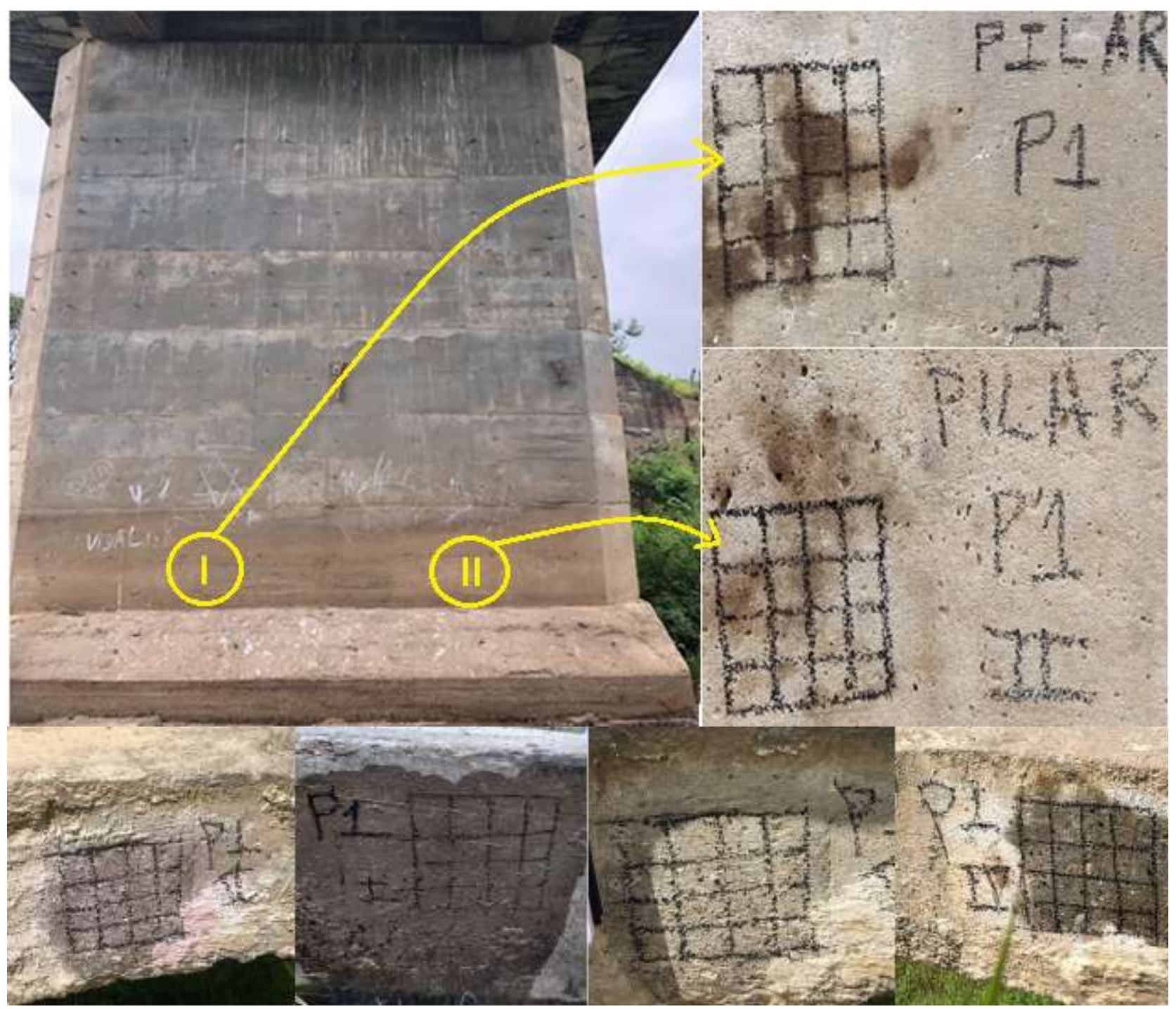

Source: Authors (2021).

It is noteworthy that access to this central pillar was difficult, given a certain depth of the river level. Porosity points were also found at the test sites. After performing and collecting data from all points, the values were categorized and treated according to Table 1. 
Table 1. Determination of the sclerometric index.

\begin{tabular}{ccccccc}
\hline \multicolumn{6}{c}{ Determination of the Sclerometric Index value (IS) } \\
Spots & I & II & III & IV & V & VI \\
\cline { 2 - 7 } 1 & 41 & 38 & 40 & 42 & 38 & 32 \\
2 & 36 & 38 & 38 & 42 & 32 & 30 \\
3 & 36 & 42 & 34 & 34 & 34 & 32 \\
4 & 34 & 42 & 36 & 38 & 34 & 32 \\
5 & 30 & 38 & 36 & 38 & 36 & 30 \\
6 & 38 & 38 & 34 & 38 & 40 & 34 \\
7 & 38 & 40 & 34 & 34 & 40 & 30 \\
8 & 40 & 40 & 32 & 34 & 34 & 30 \\
9 & 32 & 38 & 32 & 46 & 40 & 28 \\
10 & 36 & 40 & 30 & 38 & 42 & 34 \\
11 & 36 & 38 & 32 & 40 & 32 & 30 \\
12 & 34 & 40 & 32 & 46 & 36 & 34 \\
13 & 32 & 36 & 34 & 42 & 42 & 30 \\
14 & 28 & 36 & 34 & 38 & 40 & 34 \\
15 & 34 & 36 & 34 & 40 & 36 & 30 \\
16 & 34 & 38 & 30 & 40 & 40 & 30 \\
Average & 34,94 & 38,63 & 33,88 & 39,38 & 37,25 & 31,00 \\
$>10 \%$ & 38,43 & 42,49 & 37,26 & 43,31 & 40,98 & 34,10 \\
$<10 \%$ & 31,44 & 34,76 & 30,49 & 35,44 & 33,53 & 27,90 \\
Actual average & 35,00 & 38,63 & 33,67 & 39,64 & 37,33 & 31,00 \\
Adopted average & 35 & 39 & 34 & 40 & 37 & 31 \\
\hline
\end{tabular}

Source: Authors (2021).

In each area, the arithmetic mean was obtained through the analyzed points. Then, according to NBR 7584 (ABNT, 2012), sclerometric indices of points that had a value greater than or less than $10 \%$ of the value of the arithmetic mean were discarded. With these excluded indexes, a new average (real average) was recalculated only with the values that remained.

After obtaining the real average values, there is a need to obtain the values of the characteristic resistance to compression, since the value found is the surface hardness. For that, the correlation between surface hardness and compressive strength was performed (Figure 5).

Figure 5. Correlation curves between surface hardness and compressive strength of concrete.

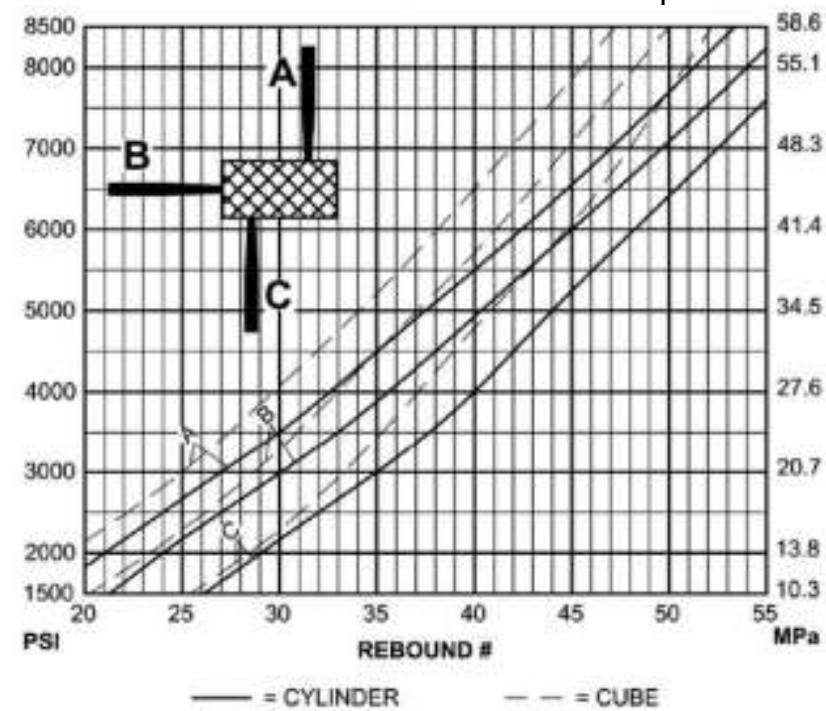

Source: Adapted from Escobar, Cruz e Fabro (2008). 
For this study, the sclerometer was used horizontally, therefore, the curve used was that of position A. Based on the correlation between surface hardness and compressive strength, was determined the compressive strength (Table 2).

Table 2. Determination of compressive strength.

\begin{tabular}{ccccccc}
\hline \multicolumn{6}{c}{ Determination of compressive strength (Fc) } \\
\hline \multirow{2}{*}{ Spots } & \multicolumn{2}{c}{ Walkway 1 } & \multicolumn{2}{c}{ Walkway 2 } & \multicolumn{2}{c}{ Pillar } \\
\cline { 3 - 7 } & I & II & III & IV & I & II \\
\cline { 3 - 7 } SI Actual & 35,00 & 38,63 & 33,67 & 39,64 & 37,33 & 31,00 \\
SI Adopted & 35,00 & 39,00 & 34,00 & 40,00 & 37,00 & 31,00 \\
Fc & 31,00 & 38,00 & 30,00 & 40,00 & 34,00 & 24,00 \\
\hline
\end{tabular}

Source: Authors (2021).

Performing analysis as the results obtained (Table 2), it can be identified that the resistance values found had ranges of variation, even if it is the same element analyzed. For that, a graph was elaborated with averages obtained (Figure 6).

Figure 6. Comparison of resistances between elements.

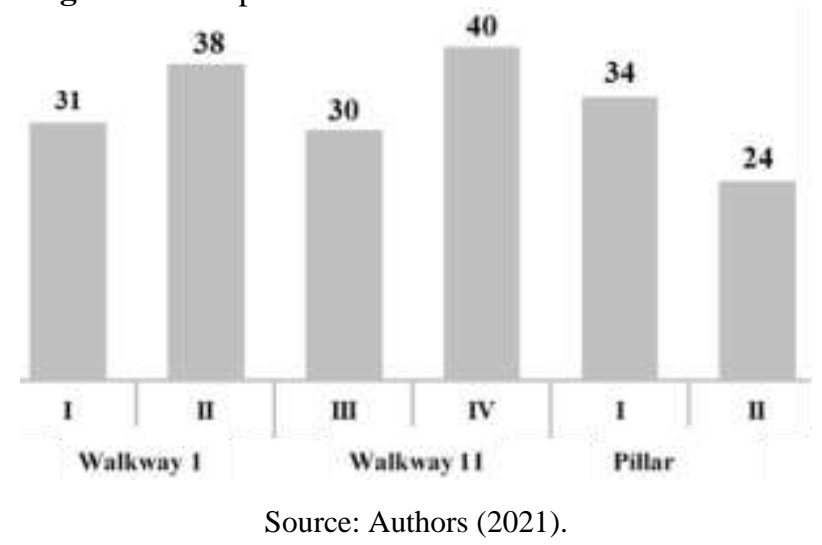

Based on the results found (Table 2 and Figure 6) readings performed, different resistances were obtained. It is possible to categorize several possible causes for such events, from the concrete production stage to the conditions of launching, densification and curing. Also, the porosity at the test site may have interfered with this data discrepancy.

Although the values found show differences between them, it can be seen that the global average is above $30 \mathrm{MPa}$, meaning that, in terms of durability and loss of performance, analyzing in a generic way, the concrete is in good usage. Following the performance of the tests, studies on the carbonation on the surface of the bridge showed that it was already carbonated on its surface (Figure 7).

Figure 7. Carbonated area.

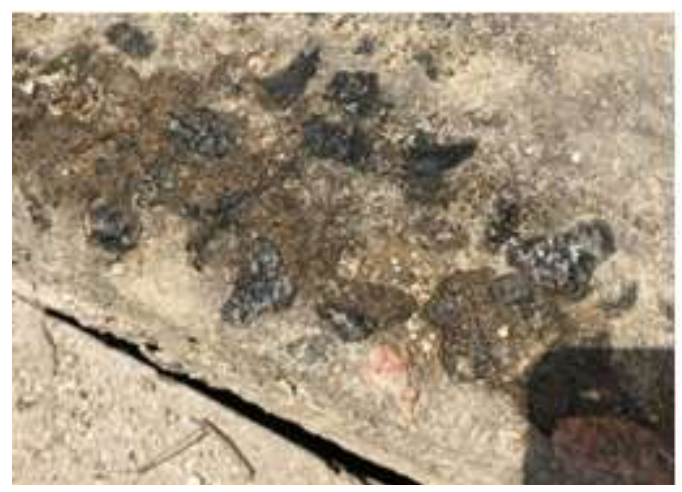

Source: Authors (2021). 
It can be identified (Figure 7) that upon contact with the phenolphthalein solution, the surface soon became colorless, thus demonstrating that it is already with low alkalinity, proving that it is already in an active carbonation stage.

It should be noted that it was not possible to carry out the test in more depth in the concrete, until the contact with the reinforcement for spraying the solution, due to authorization and logistics issues. It is emphasized the need for additional tests with respect to carbonation to more accurately identify the depth of carbonation. Finally, in terms of identifying efflorescence in the structure, points of high incidence were not identified, with only a few points standing out, as shown in Figure 8.

Figure 8. Efflorescence incidence spots.

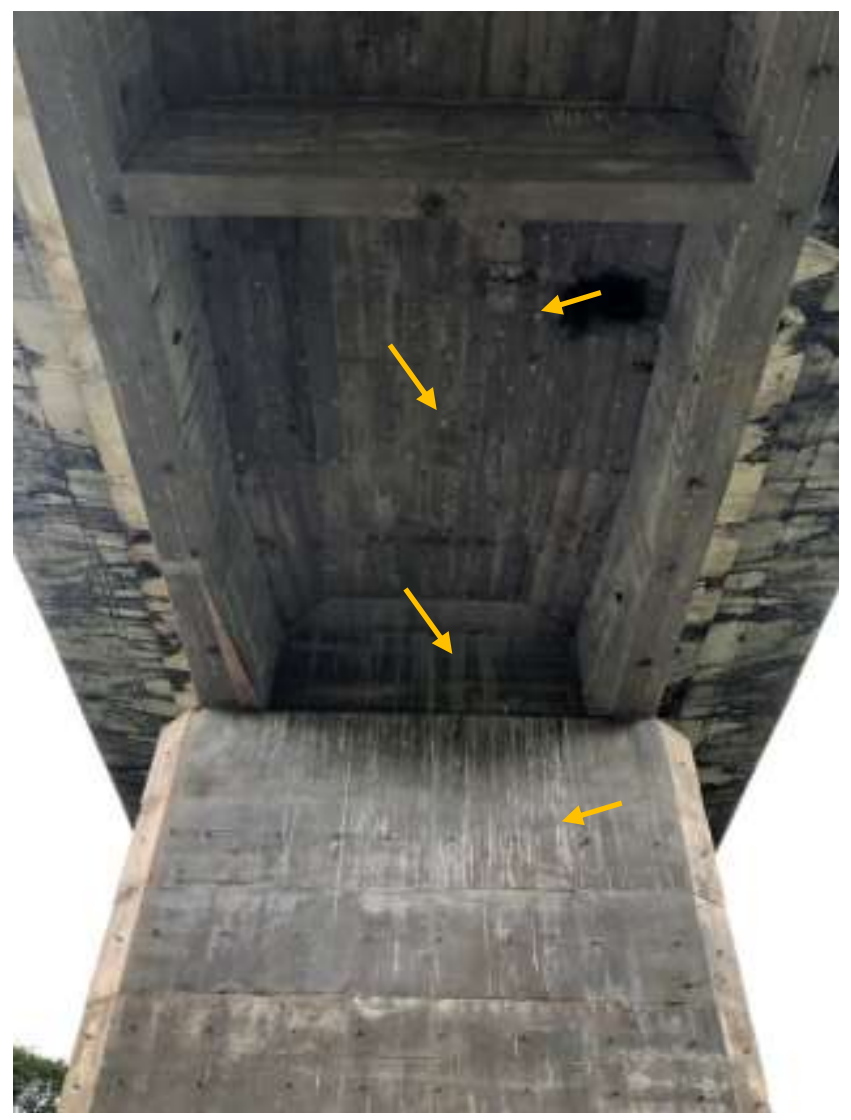

Source: Authors (2021).

As can be seen in the figure above, some points of incidence of efflorescence were observed. In addition, no exposed reinforcement points with corrosion problems were found. Thus, due to the current conditions of the bridge, even with little maintenance, it is considered that the bridge is in a regular state regarding its performance.

\section{Conclusion}

The importance of carrying out periodic inspections on bridges was highlighted, as well as in all types of buildings, with a view to guaranteeing performance and safety to users. With the sclerometry test, it was possible to estimate the compressive strength, so that the maximum estimated strength was $40 \mathrm{MPa}$, with an overall average of $30 \mathrm{MPa}$.

In terms of carbonation, it was identified that part of the structure was already carbonated, requiring better deepening, more in-depth tests and also monitoring of structural elements, in order to promote solutions in the short, medium and long terms. Regarding the effects of efflorescence, few points were identified. There are also no problems with exposed reinforcement with corrosion problems. 
In general, the bridge has, until then, been in a regular state of performance. However, the need to carry out continuous inspections with preventive maintenance is emphasized, in order to avoid future damage and prolong the useful life of the analyzed bridge.

\section{References}

Andrade, T. \& Silva, A. J. C. (2005). Patologia das Estruturas. Concreto: Concreto: Ensino, Pesquisa e Realizações. IBRACON.

Associação Brasileira de Normas Técnicas. (2014). NBR 6118. Projetos de estruturas de concreto - Procedimento. Brazil.

Associação Brasileira de Normas Técnicas. (2012). NBR 7584. Avaliação da dureza superficial pelo esclerômetro de reflexão - Método de ensaio Procedimento. Rio de Janeiro, Brazil.

Associação Brasileira de Normas Técnicas. (2020). NBR 16747. Predial inspection - Guidelines, concepts, terminology and procedure. Rio de Janeiro, Brazil.

BS EN 14630:2006. (2006). Products and systems for the protection and repair of concrete structures, Test Methods, Determination of Carbonation Depth in Hardened Concrete by the Phenolphthalein Method. British Standards Institute, London.

Candia, A. L. (2017). Metodologia para avaliação de estruturas de concreto armado degradadas utilizando ensaios dinâmicos. 2017. Dissertação de Mestrado. Universidade Federal de Viçosa. https://locus.ufv.br//handle/123456789/17678

Couto, J. P. \& Couto, A. M. (2007). Importância da revisão dos projectos na redução dos custos de manutenção das construções. In: Congresso Construção, Coimbra. http://hdl.handle.net/1822/8754

Euqueres, P. (2011). Metodologia de inspeção em estruturas de pontes de concreto armado. Dissertação de mestrado. Universidade Federal de Goiás. http://repositorio.bc.ufg.br/tede/handle/tede/9949

Escobar, C. J.; Cruz, D. A. \& Fabro, G. (2008) Avaliação de desempenho do ensaio de esclerometria na determinação da resistência do concreto endurecido. In: 50 Congresso Brasileiro do Concreto. Rio Grande do Sul. site.abece.com.br/download/pdf/e-Artigo049-2011.pdf

Helene, P. R. L. (1992) Manual prático para reparo e reforço de estruturas de concreto. (2a ed.), Pini.

John, V. M. \& Gleize, P. J. P. (2017). Materiais de Construção Civil e Princípios de Ciência e Engenharia dos Materiais. (3a ed.), IBRACON.

Mehta, P. K. \& Monteiro, P. J. M. (1994). Concreto: Microestrutura, Propriedades e Materiais. Pini.

Neumann Junior, C. (2019). Avaliação do processo de lixiviação em concreto massa o caso de Itaipu. Dissertação de Mestrado. Universidade Federal da Integração Latino-Americana. http://dspace.unila.edu.br/123456789/5223

Pamponet, R. \& Sánchez, J. M. M. (2016). O Engenheiro Emílio Baumgart e a Arquitetura Brasileira em Concreto Armado da Primeira Metade do Século XX. In: IX Congresso Brasileiro de Pontes e Estruturas, 2016, Rio de Janeiro. Anais. Rio de Janeiro: CBPE. http://abpe.org.br/trabalhos2016.htm

Possan, E. (2004). Contribuição ao estudo da carbonatação do concreto com adição de sílica ativa em ambiente natural e acelerado. Dissertação de Mestrado. Universidade Federal do Rio Grande do Sul. https://lume.ufrgs.br/handle/10183/8524

Sadati, S.; Arezoumandi, M.; Khayat, K. \& Volz, J. S. (2016). Shear performance of reinforced concrete beams incorporating recycled concrete aggregate and high-volume fly ash. Journal of Cleaner Production. 115, 284-293. https://doi.org/10.1016/j.jclepro.2015.12.017

Scrivener, K. L. (2014). Options for the future of cement. The Indian Concrete Journal, 88(7), 11-21. https://pt.scribd.com/document/464889739/Options-forthe-future-of-cement

Soares, R. G. P. (2017). Análise dos fatores intervenientes da fissuração de placa de piso de concreto apoiado sobre lajes de concreto armado. Dissertação de Mestrado. Universidade Federal de Pernambuco. https://repositorio.ufpe.br/handle/123456789/24635

Wajdowicz, C. C. (2017). Elaboração de estrutura analítica de partição (EAP) para orçamentos referentes à recuperação das principais manifestações patológicas em pontes e viadutos de concreto armado. Dissertação de Mestrado. Universidade Federal do Paraná. https://acervodigital.ufpr.br/handle/1884/60095 